\title{
GENDER ISSUE IN THE UKRAINIAN LANGUAGE TEACHING TECHNIQUES
}

\author{
SVITLANA YERMOLENKO, TETIANA SIROSHTAN
}

\begin{abstract}
The article deals with the present day problem of gender education of schoolchildren and students. It was found out, that in Ukraine the gender issue is only in the initial stage of study, although its interdisciplinary horizons are limitless. Relevance of the article is in the fact that the authors suggest studying the gender issue at the methodic level, namely through teaching syntax at the higher educational institutions. In order to achieve this aim the article provides brief characteristics of the gender issue in different aspects; the article is based upon the contemporary studies of the scientists who represent various social and linguistic sciences.

The conceptualization of gender includes such cultural categories as masculinity and femininity, the process of the evolutional development of the oldest archetype opposition "man-woman". The gender issue is directly connected with the language personality. Among the Ukrainian phraseological units there are a lot of such ones which stress the social status of men but not women. This fact lets us hope for the further study of the gender issue in the language teaching technique, namely at the level of syntax and text linguistics. First, it is an internal content of the texts proposed for scrutiny (gender education), and secondly, these are structural changes at the lexical and grammatical level (the use of words which denote jobs and professions in different functional styles), third, speech correction of both sexes representatives, and finally, the development of androgynous personality that combines the best of the social features of both sexes (love of children, patriotism, kindness, courage, compassion, sensitivity, courage, pragmatism, etc.). We consider the main principles of teaching Ukrainian syntax in the gender teaching technology as follows: dialogism, problematic, compliance with the age and individual characteristics of students, emotionality, psychology, gender identity principle. While looking for the ways to improve the language teaching techniques, especially in the field of syntax, teachers can make use of the proposed tasks at practical classes in higher educational institutions and at the lessons of Ukrainian in comprehensive schools.
\end{abstract}

Keywords: education, gender issue, teaching techniques, the Ukrainian language.

\section{INTRODUCTION}

Gender issue has always excited the human interest but its systematic study began in the second half of the $20^{\text {th }}$ century.

It is explained by the fact that patriarchal principles of the social life are getting destroyed. Women alongside with men take the highest positions in the social hierarchy. Thus, so-called "genuinely masculine occupations" are taken by women while "genuinely feminine ones" are taken by men. For 
example, a nurse - a male nurse; a milkmaid - a milkman; a waiter - a waitress; a schoolmaster a schoolmistress etc.

Unfortunately, at present time the gender issue remains open due to a number of reasons.

Well-known Ukrainian researcher Lesya Stavytska believes that "linguists have always been interested in the sphere of masculine and feminine language worlds, in the general and particular communicative strategies, in specific discourse practices and ways of the world conceptualization by different sexes through the language" [21].

Hence, we can claim that the gender issue is directly connected with the language personality. The hypothesis of the language relativity developed by Edward Sapir [9] and Benjamin Warf [25] affirms: the language is not only the society product, but it is also means of its thinking and mentality development. The German scholar Leo Weisgerber [13] first spoke about the language personality at the beginning of the $20^{\text {th }}$ century. The relevance of the problem is confirmed by the contemporary scholars S. Shirley and R. Miller in the work: "The American Indian Languages: Cultural and Social Contexts" [18].

\section{Academic Literature Review}

What is the "language personality" in modern understanding?

The idea of the "language personality" was introduced for the common use by Y. Karaulov [8], who claimed that the "language personality" is a person who has abilities to create and receive the texts which are different in the degree of their structural and language complexity, profundity and precision of the reality reflection and certain ideological focus.

Mastering of language, its lexis, grammar, stylistics and pronunciation create inner image of the worldview of all people and each person separately. Meanwhile, rapid development of linguistics, linguo-didactics, methods of teaching and learning of foreign languages in the second half of the $20^{\text {th }}$ century put in the forefront the theory of language personality together with its principles of the primary, secondary, tertiary etc. personality.

The language personality, in Y. Karaulov's opinion, has three levels: verbally semantical (the ability to communicate in everyday life), cognitive (the ability to create individual cognitive space) and pragmatic (the ability to define motives of the personality's speech behaviour).

Thus, coding and decoding of information takes place on condition of the three levels of the personality's communicative space interaction. The conception of the three-level language personality is differentiated to the three types of communicative demands (contact, informational and influential), and also to the three constituent parts of the process of communication (communicative, interactive and perceptional).

Sharing the views of the forerunners, I. Kahanets [7] suggests language socio-types: ethically intuitional introvert (the pseudonym "Peacemaker") and logically sensory extravert (the pseudonym "Administrator"). The "Peacemaker" is characterized by a more developed sensual sphere and it is mainly characteristic of women's speech, whereas "Administrator" is rational and is quite noticeable in the speech behavior of men.

Psychological aspect in gender. Both male and female sexes can be "language personality". Their opposition is fundamental for the human culture. The gender issue is essential for understanding the language personality. In linguistics gender issue is extensively studied at the lexical and phraseology levels, while grammar level is given little attention. Recent times are marked by the emergence of articles which study the gender issue at the level of word-building.

Relevance of the article is in the fact that the authors suggest studying the gender issue at the methodic level, namely through teaching syntax at the higher educational institutions. In order to achieve this aim the article provides brief characteristics of the gender issue in different aspects; the article is based upon the contemporary studies of the scientists who represent various social and linguistic sciences.

Let's find out first of all what is included in the concept of "gender"?

The term "gender" (from English 'Gender' - the state of being male or female) is rightly considered inter-disciplinary. It covers the problems of a number of sciences: philosophy, sociology, political 
science, psychology, pedagogy, linguistics, literary criticism, ethnolinguistics, sociolinguistics etc. It implies, firstly, the psychological aspect. "Gender studies is a field of interdisciplinary study and academic field devoted to gender identity and gendered representation as central categories of analysis. This field includes women's studies (concerning women, feminism, gender, and politics), men's studies, and LGBT studies. Sometimes, gender studies are offered together with study of sexuality. These disciplines study gender and sexuality in the fields of literature, language, history, political science, sociology, anthropology, cinema, media studies, human development, law, and medicine. It also analyzes race, ethnicity, location, nationality, and disability" [5].

Sex can be looked upon as a category both biological and social. "Gender" is a social construction kit embracing social possibilities of each sex in education, career development, and access to power, family roles and reproductive behavior. It concerns no anatomy and physiology features which differentiate men from women, but socially developed features found in femininity and masculinity [6].

Historians do not record any gender differences in prehistoric society when man struggled just for survival. After the time matriarchy was succeeded by patriarchy men's activity subdued both the nature and the women. Gender inequality got firmly established in culture together with social progress.

The subject of study in gender psychology deals with the following concepts: femininity, masculinity, and androgyny. They relate to gender identity, which is the basic characteristic of personality. This is a set of socio-cultural norms and stereotypes of behavior characteristic of representatives of a certain gender in the relevant socio-historical and socio-cultural situation [20].

"Femininity (also called womanliness or womanhood) is a set of attributes, behaviors, and roles generally associated with girls and women. Femininity is partially socially constructed, but made up of both socially-defined and biologically-created factors. This makes it distinct from the definition of the biological female sex, as women, men, and transgender people can all exhibit feminine traits" [4].

"Masculinity is a set of qualities, characteristics or roles generally considered typical of, or appropriate to, a man. It can have degrees of comparison: "more masculine", "most masculine"'. The opposite can be expressed by terms such as "unmanly"' or epicene. A near-synonym of masculinity is virility (from Latin vir, man). Constructs of masculinity vary across historical and cultural contexts. The dandy, for instance, was regarded as an ideal of masculinity in the $19^{\text {th }}$ century, but is considered effeminate by modern standards" [11].

Androgyny is a combination of both women-like (feminine) and men-like (masculine) qualities in the individual. Androgyny personality receives the best of the sex roles. Psychological androgyny is associated with high self-respect, efficient performance of the parental role, achievement motivation, inner feeling of welfare [6]. "Androgyny refers to the combination of masculine and feminine characteristics. Sexual ambiguity may be found in fashion, gender identity, sexual identity, or sexual lifestyle. It could also refer to biological intersex physicality, especially with regards to plant and human sexuality" [1].

In conclusion it can be said that the primary factor in gender is the psychological one, which determines the influence of femininity and masculinity on the personality's behavior.

However, in recent times one can follow the process of patriarchy masculinity destruction, especially on the level of the personality socialization, though this process has not taken shape of any social system yet.

Social aspect in gender. According to this idea, the next important factor in gender is a social aspect.

Socialization allows to perform reforms in various social spheres, especially in the language one; is has become a part of contemporary language policy in a number of countries in the whole world. Gender differentiation, as a natural process, in which biological differences between man and woman are given sociological meaning, is reflected in the speech behavior of the social subjects. The application of the extra linguistic approach to the language devices functioning in speech suggests that public gender relations between the communication parties should be considered and it gives a possibility to reconsider the language sign as means of self-actualization of the individual who represents national and universal human values. 
The author of "You just do not understand me. Women and men in conversation," D. Tannen outlines differences in behavioral models by gender and argues that linguistic behavior of men is directed to achieve and maintain independence, high status. Instead, a woman expects society nonconflict, emotional, and brightness [23].

The characteristic phenomenon accompanying the gender issue in its social aspect is "sexism". "Sexism is prejudice or discrimination based on a person's sex. Sexist attitudes may stem from traditional stereotypes of gender roles, and may include the belief that a person of one sex is intrinsically superior to a person of the other. A job applicant may face discriminatory hiring practices, or (if hired) receive unequal compensation or treatment compared to that of their opposite-sex peers. Extreme sexism may foster sexual harassment, rape and other forms of sexual violence" [17].

In its broad sense sexism is orientation which makes one sex inferior to the other. Language sexism is determined as manifestation of asymmetries aimed against women in the language system. On the grammar level it can be seen as the advantage of the grammar masculine gender over feminine gender. Thus, the entire initial forms for the content words of adjective, participle and adjectival pronoun which have the paradigm of gender are masculine. If the speaker implies representatives of different sex or a group of people of different sex regarding the occupation, person's social status, his hobby etc. the advantage is also given to the masculine gender.

The example of practical use of gender correct norms in other countries, e.g. the USA, can be the document on liberation of English from discriminative signs which was issued by the American National Council of Teachers of English (1974). It offers to use the language free of sexism in all the life spheres. According to this document it is recommended:

1) not to use generalized man, instead such words as humanity, human, beings, people should be used;

2) to use the same occupation words both for men and women: chair, presiding, officer, moderator, head, chairperson (instead of chairman, chairwoman) and others; while choosing a numeral for the indefinite forms one should use he or she (e.g.: after such nouns (person, counterpart, individual), and indefinite pronouns (one, someone)) [22]. This norm is generally accepted and is thought to be politically correct. For instance, gender component is kept in mind while making up documents by mass media, e.g.: the New-York Times writing about members of the Congress uses both words congressman and congresswoman ("He was running an intense campaign against Rosa L. DeLauro, a congresswoman from Connecticut... When his slate knocked off three of Mr. Menendez's allies, he handed the congressman an embarrassing defeat") [12]. Correspondingly, it is recommended to use the same definitions by occupation both for men and women etc.

In Germany (Lower Saxony), for example, an official document on the position of statesmen was accepted, in which the positions that originally have had the suffix of the masculine gender have attained the suffix of the feminine gender no matter who is further spoken of [10].

In Ukraine the gender issue in language still remains poorly studied; there is no program for its fundamentals consistent embodiment into the language life of society. However, democratic reforms in all the spheres of social life favour gradual fixation of gender correct norms in the Ukrainian language. An example is the new orthography of the Ukrainian language dated 2019. It pays particular attention to feminine nature. Many nouns of the female genus, inherent in colloquial language, have now become a literary norm: дизайнерка, директорка, редакторка, філологиня [designer, director, editor, philology] [24].

\section{Methodology}

The general methodology of the study includes scientific achievements of linguists in the study of the gender issue in the language (O. Horoshko, G. Kreidlin, B. Nikolson, A. Petrenko, D. Petrenko, Y. Puzyrenko, V. Shtadler, L. Stavyts'ka, G. Vidmark, etc.). Attention was drawn to the pedagogical basis of research of Ukrainian and foreign scholars on the role of gender education in the formation of personality; the main provisions of psychological and pedagogical works on the priority role of sexual education in the formation of a person capable of culturally meaningful relations with the opposite sex; scientific conclusions of methodologists on the problem of the formation of positive gender qualities of students. 


\section{ANALYSIS AND DisCUSSION}

The point is, in what way the Ukrainians perceive the concept "woman" and "man"? Which characteristics do they ascribe to these concepts?

Conceptualization of gender is understood as cultural categories of masculinity and femininity, the evolution process of the oldest archetypal opposition "man - woman". "Gender approach to the structuring of "conceptual questionnaire" as a basis of the gender worldview allows to expose gender stereotype through phraseological representation of simple and complex sub-concepts: "appearance", "mental abilities", "psycho-emotional and volitional powers" and others" [16]. In proverbs and sayings masculine characteristics are positive, whereas feminine ones are, on the contrary, negative. For example, Хоч чоловік як жаба, а все дужчий, як баба [Even if a man looked like a frog, he would be better than a woman]. Чоловікам на лопату Бог сили наклав, та ще й притоптав, а жінкам на вила, та $\breve{u}$ mо струсив [God put much strength on the man's spade, and besides, stamped it down, as for the women, God put their strength on a hayfork, and shook a little off].

According to the stereotype the female sex is called weak and the male one is strong. If a man is shy and effeminate, he is called "sissy". Thus, a weak sex can be defined as representing a shy, chickenhearted, effeminate person.

Gender stereotype of masculine characteristic displays itself in the mind of modern people in a way of stereotyped clichés like: male character, male bonding, male mind, and recently - a real man. One of the examples is an advertisement of vodka: "MEDOFF" - for real men. Correspondingly, there are feminine stereotypes-clichés, like: female friendship, female mind. Their evident negative connotation is expressed in the toast: Female friendship is like friendship between a tortoise and a snake while they are swimming amidst the ocean: the tortoise would gladly throw off the snake, but it is afraid of its venom; the snake would bite the tortoise, but it is afraid getting drowned.

The research of men's and women's speech demonstrates that women's communicative behavior is often expressive, too emotional, not always coherent, which is proved by the idiom woman's reason. Stereotypical ideas of the women's speech behavior are associated with such idioms as баб'яче голосіння [woman's nagging]; язиката Хвеська [talkative Khves'ka]; сорока на хвості принесла [a magpie has brought on its tail]; не поможе бабі й кадило, коли бабу сказило [even a thurible won't help a woman if she is as mad as a wet hen] etc.

While studying gender stereotypes, Lesya Stavytska analyzed the words "mother" and "father". She has drawn such a conclusion:

- Mother is a successor and guardian of the family line; mother and a child is a symbol of life and eternity.

- In the field of cordiocentric Ukrainian character, the concept of "cordiality" which is the central one for the Ukrainian linguistic culture is realized just in the association area "mother".

- Father is the head of the family, master and a good landlord.

- Father is a symbol of big and little motherland; the man possessing the nimbus of sanctity [21].

In linguistics the issue of gender differentiation in language and speech is fundamentally studied by such outstanding scholars as G.Vidmark, G. Kreidlin, O. Horoshko, B. Nikolson, Y. Puzyrenko, A. Petrenko, D. Petrenko, L. Stavyts'ka, V. Shtadler and others.

Gender study on the language level has embraced all grammar sections. For instance, a unit of study of gender word-formation level is the feminitive. The researcher of the word-building structure of nouns of feminine in the New Ukrainian language S. Semeniuk observes: "During all the periods of development of the Ukrainian linguistics the feminitives used for names of the male sex representatives on their social position were studied either on the certain stage of development of the new Ukrainian language or were offered the analysis of just separate lexical or word-formative sub-groups and formants" [15]. The word-building structure of the nouns of the female and male genus was studied by other scientists, in particular P. Bilousenko [2], T. Siroshtan [19]. However, till now this issue remains unresolved. The establishment of the sub-system of the mentioned male and female personal names has not been the object of the complex study yet. 
In the $19^{\text {th }}$-early $20^{\text {th }}$ centuries the group of feminitives based on a social status was formed. For ехатрle: господар - господиня, дворянин - дворянка, жебрак - жебрачка, раб - раба, слуга - служниия [landlord - landlady, nobleman - noblewoman, beggar man - beggar woman, bondman - bondmaid, manservant - maidservant].

Gender peculiarities are vividly expressed in every-day speech, namely in compliments, which are traditionally addressed by men to women, e.g.: вельмишановна панно, вам до лиия ияя сукня інамисто [My dear Miss, this dress and necklace suits you pretty well], и ви так молодо виглядаєте, вам напевно нема і тридияли [you look so young, you are sure not in your thirties yet] etc.

Traditionally male roles are more significant while the female ones are restricted by family environment, as the former automatically become dominant in social life.

Thus, for instance, the names of professions and jobs in official documents are used in the male gender more often. In the State Classifier of professions in Ukraine there are 7, 000 professions and jobs which are used in the male gender and only 38 are used in the form of the female one. On the grammar level, especially while forming word combinations with the given professions and jobs, only adjectives or verbs in the male gender are used. For example: бухгалтер фірми виявив, стариий інспектор комісіі записав, висококваліфікований кухар переміг [the accountant of the firm found out, the senior inspector of the commission wrote down, highly-qualified cook has won].

Among the Ukrainian phraseological units there are a lot of such ones which demonstrate the social status of men, not women. For example: чи пан, чи пропав [man or mouse]; щвецзь знай своє шевство, а $в$ кравецтво не лізь [a shoemaker knows his business, and a tailor should not interfere]; як не коваль, то й рук не погань [if not a smith, don't soil your hands]; художник у душі [the artist in heart].

Forms of the female gender are acquired only by adjective pronouns and verbs agreeing with surname, position held, profession etc. For example: Ця бухгалтер фірми Іванова І.В. виявила недоліки [The firm accountant Ivanova I.V. has found out some flaws].

In recent times colloquial, belles-letters or publicistic style in contrast to the official one widely use the parallel forms for naming professions or jobs which are not established by the State Classifier of Ukraine. For example: художник - художниця [artist - woman artist], ^ікар - лікарка [medical man medical woman], вчитель - вчителька [schoolmaster - schoolmistress], член - членка [member woman member], референт - референтка [assistant - woman assistant], редактор - редакторка [editor - woman editor]. Using these forms one should bear in mind that such forms are not acceptable in the official style as a rule.

One should also mind the context of usage for professions or jobs if the parallel forms are available, since they can either belong to different styles or have different meaning. For example: швачка [seamstress] - it is a profession which means making clothes, whereas швець [shoemaker] - it is a profession which means production of footwear, or годувальник - годувльниця [breadwinner - wet nurse]: годувальник [breadwinner] - a person who supports a family; годувальницяя [wet nurse] - a woman employed to feed another woman's baby with milk from her own breast.

Attention should be drawn to the so called "female professions", namely: доярка, медична сестра, праля, покоївка, друкарка [milkmaid, nurse, laundrywoman, housemaid, typist] etc. With the given examples one can see that these occupations have a low level of qualification, consequently the pay for the job is much lower than among the representatives of the "male professions". Thus, the gender issue requires the equal solution in the social aspect.

All the mentioned aspects of the gender issue (psychological, social, linguistic, and communicative) are also significant in the course of language teaching techniques, namely syntax. In pedagogical aspect as L. Dybka points out, educational establishments as institutes of personality's socialization have to attend to the gender culture as one of the leading factors in the identity formation of a contemporary schoolchild [3].

Experiments in Gender psychology proved that the reception of a young man or a young lady is directly associated with their sex differences: specificity of feelings, emotions, endeavour to find your own "me" and others. Therefore, teaching techniques has to consider the gender aspect in classrooms both in comprehensive and higher educational establishments. 
Having described the gender issue in various aspects, we are about to study the language phenomena in the close connection with a human being, his way of thinking, practical activity according to the social role; we are about to determine peculiarities of gender issue in contemporary educational establishments through practical embodiment in tasks which can be used in the course of teaching syntax in the higher and comprehensive educational establishments

As educational practice of teaching a language proves, teachers pay little attention to gender issue and its significance in speech. Even if such work is being done, the gender issue is given only a passing mention as being insignificant for the language teaching techniques.

Looking for ways of improving the language teaching techniques, namely syntax, teachers can take advantage of the given tasks for practical classes to use either in the higher educational establishments or at lessons of Ukrainian in comprehensive schools.

Task 1. Read phraseological units, proverbs and sayings, explain their meaning. Use them in simple sentences of your own. Which gender (male or female) are the given examples mainly used in? Why do you think so?

Здоровий як Әуб; Әужий як ведмідь; як із каменю вибитий; гарний як у барвінку купаний; стрункий, наче з дерева виструганий; пішов у ріст як заєцьь у хвіст; як денді лондонський; прибрався як пастух у Петрівку; борода по коліна, а розуму як у дитини; високий аж до неба, а дурний як не треба; розуміється як Мартин на балалайці; розумний як Оверкові штани навиворіт; впрів як Філат коло скрипки; хватається як цзиган до пасіки; крутий як варене яйце; налетів як кібецьь на курча; калатає язиком як Мар'ян батогом; блажен муж, до школи не дуж; до церкви слизько, до дівчат близько [healthy as an oak; strong as a bear; as if carved out of stone; as good-looking as if being bathed in the dogbane; slender as if carved out of wood; one has begun to grow as the hare's tail; as a dandy of London; one has got dressed as a shepherd in Petrivka (a holiday); a beard till the knees, but with the child's wit; tall up to the skies but extremely stupid; as good as Martin plays balalayka; as clever as Overko's pants inside out; having sweated as Filat with the violin; one gets down to work as the gypsy to the bee garden; as hard as a hard-boiled egg; he attacked as the hawk attacks a chicken; to wag one's tongue as Maryan cracks his whip; a blessed man but reluctant to study; the road to the church is slippery, but the road to the girls' place is short].

Task 2. Find two synonymic sentences: you should not mention the category of person in the first one and you should mention it in the second one. Explain the difference between them if there is any.

For example: викладач хімії - Викладач хімї зазначив, що неорганічна хімія вивчається в першому семестрі, тоді як органічна - у другому. - Викладач хімії Коваль О. П. зазначила, щьо неорганічна хімія вивчаеться в першому семестрі, тоді як органічна - в другому [Chemistry teacher pointed out that nonorganic chemistry is studied in the first term and the organic chemistry is studied in the second one. Chemistry schoolmistress Koval A. P. pointed out that non-organic chemistry is studied in the first term and the organic chemistry is studied in the second one.].

Викладач хімії, касир заводу, лаборант відділу, бригадир цзеху, працівник фірми, учитель школи, завідувач кафедри української мови, акушерка, буфетниц, вишивальниц, в'язальниця, ворожка, швачка, автоелектрозварник, адміністратор, бармен, водій, диспетчер, менеджер, психолог, ревізор, юрисконсульт, покоївка, бібліотекар, бухгалтер, маляр, приймальниия, сестра медична, прибирахьниця, швачка, секретар, адвокат, прокурор [Chemistry teacher, a factory cashier, a departmental assistant, a workshop foreman, a firm employee, a school teacher, Head of the Ukrainian Chair, an obstetrician, a barmaid, an embroideress, a knitter, a fortune-teller, a seamstress, an autoelectric welder, a receptionist, a barman, a driver, a switchboard operator, a manager, a psychologist, an inspector, a solicitor, a chambermaid, a librarian, an accountant, an artist, a washwoman, a nurse, a charwoman, a secretary, a lawyer, a prosecutor].

Task 3. Read the sentences. Define the functional style of the sentences. Rewrite the sentences in such a way so that to change their functional style (e.g., the colloquial style for any bookish one: official, learned, publicistic, belles-lettres etc.). What structure have the rewritten sentences attained? Why?

For example: Шістдесят з лишком років творчої праці і більще чотирьох тисяч художніх творів віддала своєму народові Олена Кульчицька - народна художницяя України. - 25 грудня святкуємо 
шістдесятип'ятиріччя народного художника України Олени Кульчицької [More than 60 years of creative work and four thousand paintings have been given to her people by Olena Kulchyts'ka, the honoured Ukrainian painter. - 25 December is the 65th birthday of the honoured Ukrainain painter Olena Kulchyts'ka].

1. Оля хоче вивчитися на лікарку або вчительку. 2. Вона була членкою Учительської громади. 3. Дикторка Надія Подоляко із своїм колегою Віталієм Вареником час від часу виходять у прямий ефір 3 інформаційними повідомленнями. 4. Із 14 жінок-редакторок у Киеві та Київській області фахову журналістську освіту мали 6, філологічну - 4. 5. Право на допомогу на дітей одиноким матерям мають одинокі матері... Якщо одинока мати (вдова, вдівецьь) уклала шлюб, то за нею зберігається право на отримання допомоги на дітей, які народилися до шлюбу. 6. До кабінету було запрошено секретарку директора Полякову А.О. 7. До кабінету було запрошено секретаря комісї Полякову А.О. 8. У конкурсі перемогла відмінницяя 8-А класу Гур'єва Л.Г. 9. У конкурсі перемогла відмінник народної освіти викладач ЗОШ № 16 Гур'єва И.Г. 10. Зарахувати на посаду друкаря офсетного друку Підмазану О.Р. 11. Зарахувати на посаду друкарки-референта Підмазану O.P. [1. Olya wants to become a teacher or a doctor. 2. She was a member of the Teachers' community. 3. News anchor Nadezhda Podolyako and her colleague Vitaliy Varenyk broadcast on-camera from time to time. 4. Among fourteen womeneditors in Kyiv and Kyiv region there were six people with professional journalist training and four people with philological one. 5. The right for the single mothers' children's allowance is given to single mothers... If a single mother (widow, bachelor) has got married, she still has a right for the allowance for the children which were born before the marriage. 6 . The director's secretary Polyakova L.A. was asked to come into the office. 7. The commission secretary Polyakova L.A. was invited into the room. 8. The best pupil of 8-A form has won the contest. 9. The best worker in popular education, a teacher of secondary school №16 Gurieva L.G. has won the contest. 10. Podmazanna O.R. is to be engaged to the position of an offset printing worker. 11. Podmazanna O.R. is to be engaged to the position of a typist].

Task 4. Read the proverbs. What kind of semantic interpretation unites them (what are they about)? What types of sentences were used? Why?

Яка неня, така й доня. Нема чого дивувати - така була й ї̈ мати. Який батько, такий син. Яке дерево, такий клин; який батько, такий син. Який дуб, такий тин; який батько, такий син. Яка вода, такий млин; який батько, такий син. Яка гребля, такий млин; який батько, такий син. Який мельник, такий млин [Like mother, like daughter. There is nothing to be surprised at - her mother was like that. Like father, like son. As the tree, so is the wedge; like father, like son. As the oak, so is the fence; like father, like son. As the water, so is the mill. As the barrage, so is the mill. As the miller, so is the mill].

Task 5. Choose from the given polite expressions those ones which, in your opinion, are used by men and those ones which are used by women, and those which are used by both men and women during business meetings (official style). What is this choice determined by? Which of the offered statements can be used under various circumstances and in any style? Why? What can you say about the syntactic structure of the sentences?

1. Привіт. Здрастуйте. Доброго ранку. Наше щзире вітання. Добрий день. Добридень. Вечір добрий. Добрий вечір. Доброго здоров'я. Я вас вітаю.

2. До побачення. До завтра. На все добре. Бувайте. Усім вітання. Мені час. До зустрічі. Скоро побачимося. Щасливо.

3. Спасибі. Дякую. Щиро дякую. Дуже дякую. Дозвольте висловити вдячність. Глибоко вдячний. Дякую від усього сериял. Ви зробили мені велику послугу. Я у великому боргу перед Вами. Складаю подяку.

4. Так. Гаразд. Обов'язково. Авжеж. Добре. Чудово. Ще б пак. Ви маєте рацію. Не заперечую. Звичайно. Безсумнівно.

5. Дякую, не треба. На превеликий жаль, ні. Ні, я не можу. Про изе не може бути й мови. Нічого подібного. Це марнування часу. Я про це іншої думки. Шкода, але я мушу відмовитися. Це неможливо.

6. Перепрошую. Вибачте. Мені дуже шкода. Даруйте за клопіт. Прошу вибачення. Вибачте, що завдав скільки клопоту. Не згадуйте про цее. 
7. Це не так? Не може изього бути? О! Тільки уявіть собі! Подумати тільки! Хто б міг подумати! Як дивно!

8. Дозвольте віррекомендувати. Дуже радий з Вами познайомитися. Це дуже люб'язно з Вашого боку.

[ 1. Hello. How do you do? Good morning. Our sincere greeting. Good afternoon. Good evening. I greet you.

2. Good-bye. See you tomorrow. Good luck. So long. My best regards to... It's time to go. See you. See you soon. Have a good day.

3. Thank you. Thanks. Thank you very much. Thanks a lot. I'm very much obliged to you. I'm grateful to you. Thank you from the bottom of my heart. You've done a great favour to me. I owe a lot to you. Heartfelt thanks to... .

4. Yes. Everything is all right. Of course. Certainly. All right. Great. I should think so. You are right. I don't mind. For sure. No doubt.

5. Thank you, I don't want to. Unfortunately not. No, I can't. It is out of the question. Nothing of the kind. It is just a waste of time. I have another opinion. Sorry, but I have to say no. It is impossible.

6. I am sorry. Sorry. I'm very sorry. Sorry to bother you. I am so sorry. I must apologize for troubling you. Don't mention it.

7. Really? It can't be true! Oh, just imagine! Just fancy! Just think of that! How very strange!

8 . Let me introduce you to.... Pleased to meet you. It's very kind of you].

Task 6. Familiarize yourself with illustrations or reproductions of famous works of Ukrainian literature (G. Kvitka-Osnovyanenko, I. Nechuy-Levitsky, T. Shevchenko, etc.). Give character to the personage, using sentences with homogeneous members (complex sentences, complicated sentences, etc.). Pay attention to the stereotypes, the formalism in the image of the characters, their activity, activity and passivity, subordination; explain whether the role of female representatives is diminished to affluent, subordinate, and the role of male representatives - to the main, governing, and active?

Task 7. For the final work, students can be offered test assignments. The example is below:

1. Language sexism is:

A. Discrimination by gender in language.

B. Representation of a woman and a man in a language.

C. Linguistic display of the biological sex

2. Language tolerance is based on:

A. Ethnicity.

B. Struggle for equal rights.

C. Religious, Ethnic and Gender Tolerance.

3. Choose sexism-masculines from the following examples:

А. мамин синочок, чодовік-невдаха, тюхтій

В. стара діва, синя панчоха, біла ворона

С. баба Яга, дісовик, русалка

4. Choose sexism-feminitives from the examples given:

А. стара діва, синя панчоха, біла ворона

В. стара діва, синя панчоха,сіра мишка

С. дама бальзаківського віку, мати-квочка, біла ворона

5. In what proverb most gender stereotypes are exploded:

А. бездоганна жінка така ж рідкість, як біла ворона

В. жіночий розум коротший за жаб̆'ячий хвіст

С. люби жінку як душу, тряси їі як грушу

6. Who are the represented folk comparisons?

Як базарна баба. Сором'яздивий, як дівчина. Носиться, як баба зі ступою. Пащекує, як баба на возі. Високий, як лоза, а дурний, як коза. Подохливий, як заєць. До праці, як ведмідь до танцю. Торохкотить, як Гаврилів млин.
A. man
B. woman 
C. husband and wife

7. For the nomination of professions, posts are most often used:

A. masculinates

B. feminates

C. masculinates and feminates

8. The specific feature of the gender Ukrainian cultural paradigm is:

A. androgyny

B. femininity

C. masculinity

9. Identify in which sentences refers to sex:

A. Women give birth to children, and men do not

B. Little girls are gentle, and boys are rough

C. Women have long hair, men are short

10. Identify in which sentences it is about gender:

A. Women have a more refined pronunciation than men.

B. Women in Ukraine receive $70 \%$ of men's wages.

C. Boar voices break when they reach maturity, and girls are not.

\section{CONCLUSIONS}

To summarize, the introduction of gender education in high school is determined by profound social and cultural changes in the life of Ukrainian society, which, in addition to the necessity of training educated, sexually explicit young people, is determined. We can acknowledge that gender issue in Ukraine is being in its initial stage of study though its interdisciplinary horizons are infinite. It lets us hope for further study of gender issue in language teaching techniques, namely at the level of syntax and linguistics of text. For the first, it is inner content of texts offered for analysis (gender education), for the second, constructive changes at the lexical, grammar level (in use of the words to name jobs, professions in different functional styles), for the third, speech correction for representatives of both sexes; finally, education of androgenic personality combining in itself the best social qualities of both sexes (love for children, patriotism, kindness, courage, mercifulness, sensuality, boldness, pragmatism etc.). We consider the main principles of teaching Ukrainian syntax in the gender teaching technology as follows: dialogism, problematic, compliance with the age and individual characteristics of students, emotionality, psychology, gender identity principle.

Gender issue is greatly significant in the modern world. In 1982 Ryan and other authors studied gender issue in English, French and Spanish in the context of its attitude to politics [14]. This gives grounds for the need to further study the methodology of teaching the Ukrainian language with a gender perspective.

\section{REFERENCES}

[1] Androgyny. Available at: http://en.wikipedia.org/wiki/Androgyny

[2] Bilousenko P.I. The History of the Suffixal System of the Ukrainian Noun (the names of the masculine species). KDPI, Kyiv, 1993. (in Ukrainian)

[3] Dybka L. A lesson - gender research. Dyvoslovo, 2 (2007), 12-17. (in Ukrainian)

[4] Femininity. Available at: http://en.wikipedia.org/wiki/Femininity

[5] Gender studies. Available at: http://en.wikipedia.org/wiki/Gender_studies

[6] Hovorun T., Kikinedzhi O. Sex and Sexuality: psychological perspective. Navchal'na knyga-Bohdan, Ternopil', 1999. (in Ukrainian) 
[7] Kahanets I. Aryan Standard: Ukrainian idea of the epoch of great transition. ASK, Kyiv, 2004. (in Ukrainian)

[8] Karaulov Y.N. Russian language and the language personality. Moscow, 2003. (in Russian)

[9] Koerner K. (Ed.) Edward Sapir - Appraisals of His Life and Work. John Benjamin, Philadelphia, 1984.

[10] Malishevskaya D. Basic concepts in the light of gender approach (through the example of the opposition "Man / Woman"). In: Phraseology in the context of culture. LRC Publishers, Moscow, 1999, 180-184. (in Russian)

[11] Masculinity. Available at: http://en.wikipedia.org/wiki/Masculinity

[12] Gettleman J. A Congressman Is Readyto Step Up in New Jersey. New-York Times (19 September 2005). Available at: www.nytimes.com/2005/09/19/nyregion/metrocampaigns/19menendez.html

[13] Radchenko O.A. Apostle of the native language. In: Weisgerber J.L. Native language and formation of spirit. Editorial USSR, Moscow, 2004. (in Russian)

[14] Ellen Bouchard Ryan and Howard Giles (Eds.) Attitudes Towards Language Variation: Social and Applied Contexts. Edward Arnold, London, 1982. Available at: http://www.ncte.org/library/NCTEFiles

[15] Semeniuk S. Formation of the word-building sub-system of feminitives for male proper names according to the social status in the New Ukrainian Language. "Ukrainska mova", 4 (2007), 65-76. (in Ukrainian)

[16] Semikolenova O.I., Shylina A.G. Gender aspect of modern language policy. Movoznavstvo, 4 (2006), 3240. (in Ukrainian)

[17] Sexism. Available at: http://en.wikipedia.org/wiki/Sexism

[18] Shirley Silver, Wick R Miller. American Indian Languages: Cultural and Social Contexts. University of Arizona Press, Tucson, 1997.

[19] Siroshtan T.V. Essays on the History of Ukrainian Word Formation (Nomina Loci of the end of the XVII - early XXI centuries). Zaporizhzhia - Melitopol, 2016. (in Ukrainian)

[20] Sizova O.F. Specificity of representing in translation the gender identity of the subject of women's poetic discourse (based on English translations from Ukrainian). Dissertation for the degree of Candidate of the Philology Sciences: 10.02.16. Taras Shevchenko Kyiv National University, Ukraine, 2007. (in Ukrainian)

[21] Stavyts'ka L. Gender stereotypes in contemporary language consciousness. According to the data of the association experiment with the words "mother, father". Dyvoslovo, 5 (2005), 47-51. (in Ukrainian)

[22] Students' Right to Their Own Language Conference on College Composition and Communication Explanation of Adoption (The following appeared as a Special Issue of CCC, Fall, 1974, Vol. XXV.). Available at: http://www.ncte.org/library/NCTEFiles/Groups/CCCC/NewSRTOL.pdf

[23] Tannen D. Gender and discourse. Oxford UP, N.Y., 1994.

[24] Ukrainian orthography, 2019. Available at: https://mon.gov.ua/ua/osvita/zagalna-serednyaosvita/navchalni-programi/ukrayinskij-pravopis-2019. (in Ukrainian)

[25] Warf B.L. Relations between norms of behavior, thinking and language, 2013. Available at: http://sprachinsel.com/index.php?option=com_content\&task=view\&id=72\&Itemid=61

Address: Svitlana Yermolenko, Tetiana Siroshtan, Melitopol Bogdan Khmelnytsky State Pedagogical University, 20, Hetmanska Str., Melitopol, 72300, Ukraine.

E-mail: tanyasiroshtan1982@gmail.com; s.ermolenko@gf.sumdu.edu.ua

Received: 27.12.2019; revised: 18.02.2020.

Єрмоленко Світлана, Сіроштан Тетяна. Гендерне питання у методиці навчання української мови. Журнал Прикарпатського університету імені Василя Стефаника, 7 (1) (2020), 81-92.

У статті розглянуто сучасну проблему гендерної освіти школярів та студентів. 3'ясовано, що в Україні гендерне питання є лише на початковій стадії вивчення, хоча його міждисциплінарні 
горизонти є безмежними. Концептуалізація гендеру включає такі культурні категорії, як маскулінність та жіночність, процес еволюційного розвитку найдавнішої архетипової опозиції «чоловік-жінка». Серед українських фразеологічних одиниць дуже багато таких, які підкреслюють соціальний статус чоловіків, але не жінок. Цей факт спонукає до подальшого вивчення гендерної проблематики в методиці навчання мови, а саме на рівні синтаксису та текстової дінгвістики. Поперше, це внутрішній зміст текстів, запропонованих для ретельного вивчення (гендерна освіта), подруге, це структурні зміни на лексичному та граматичному рівні (використання слів, що позначають рід занять та професії у різних функціональних стилях), по-третє, удосконалення усного мовлення представників обох статей i, нарешті, розвиток андрогінної особистості, що поєднує в собі найкращі соціальні особливості обох статей (дюбов до дітей, патріотизм, доброта, мужність, співчуття, чуйність, сміливість, прагматизм тощо). Шукаючи шляхи вдосконалення методики викладання мови, особливо у галузі синтаксису, вчителі можуть використовувати запропоновані завдання на практичних заняттях у вищих навчальних закладах та на уроках української мови у загальноосвітніх школах.

Кдючові слова: освіта, гендерне питання, методика викладання, українська мова. 